\title{
The Initial Puzzle: Why Governments in Dominant Party Systems Engage with the EU on Good Governance Reform, or Not
}

When choosing to cooperate on governance reforms, the EU and African governments have to assess their choices in light of domestic and international, short- and long-term costs and benefits that this cooperation entails. Sometimes the EU's and African governments' preferences converge and cooperation provides joint gains; sometimes, preferences diverge. The EU and African governments do not make their decisions about when, how and on what aspects of governance reforms they want to cooperate in isolation. Their decisions are deeply embedded in negotiations about development aid and interests in the wider network of bilateral economic, security and political cooperation. The costs that the EU and African governments might have to bear when deciding to cooperate on governance reforms may be outweighed by benefits reaped from other parts of the relationship.

Whereas the EU's motives for and interests in promoting governance reforms are comparatively well researched, much less is known about the factors that shape African governments' willingness to engage with the EU. This is the central concern of this book. This chapter develops an analytical grid to assess African governments' responsiveness towards EU demands to engage in governance reforms and identifies the factors that shape African governments' response strategies.

The analysis adopts a basic, rationalist framework for interaction. Actors are assumed to make decisions about cooperation consciously and to base

C. Hackenesch, The EU and China in African Authoritarian

Regimes, Governance and Limited Statehood, https://doi.org/10.1007/978-3-319-63591-0_2 
their decisions about engaging in cooperation on rational (im)material costbenefit calculations shaped by the information available to them and by their underlying belief systems. The basic interest for both-the EU and African governments-is to remain in power, and their decisions to cooperate on governance reforms are also informed by this basic interest. EUAfrica cooperation on governance reforms can then be conceived of as a situation of strategic interaction in which both sides have a preference for a specific outcome of the cooperation and a certain amount of bargaining power to influence that outcome. This framing builds on recent research which has conceived donor-recipient relations in general (Whitfield and Fraser 2009) and the implementation of the EU's good governance instruments in particular (van Hüllen 2015) as a situation of international cooperation.

According to Keohane's $(1984,51)$ seminal definition, cooperation occurs 'when actors adjust their behavior to the actual or anticipated preferences of others, through a process of policy coordination'. This definition presumes that actors' behaviour is directed towards some goal(s) and that cooperation provides gains or rewards to the actors. These rewards do not have to be equally large for both actors. But cooperation emerges only if the interaction leaves both better off (or at least not worse off) than unilateral action and no agreement. Through cooperation, actors do not necessarily seek to help each other; the adjustment of policies is done in anticipation that it will bring gains for one's own situation (Milner 1992, 468).

Cooperating on governance reforms confronts the EU and African governments with three cost-benefit calculations. First, both sides assess the immediate benefits and costs that cooperation on governance reforms entails. Second, they analyse their interest in the bilateral relationship and weigh the benefits and costs of cooperating on governance reforms against those of engaging in other areas and policy fields within the context of their bilateral relations (e.g. trade, investment or security cooperation). Third, they weigh the costs and benefits of their bilateral cooperation against opportunities for cooperation offered by third actors, such as China. In this regard, cooperating on governance reforms can be described as a 'two-level game' (Putnam 1988), where the EU's and African governments' preferences for cooperation and their bargaining power are substantially shaped by the domestic costs and benefits that cooperation entails.

EU-Africa cooperation on governance reforms is highly asymmetric in several ways. The instruments and the institutional framework for cooperation are substantially shaped by the EU: the EU makes an offer for 
cooperation; it asks African governments to engage in political dialogue, aid policy dialogues, the implementation of governance aid or to comply with EU demands for political reforms. African governments then decide if they want to engage with the EU. Through its agenda-setting power, the EU can substantially influence the outcome of cooperation. By promoting a specific content of good governance and by using specific instruments to promote governance reforms, the EU pre-defines and structures possible sets of outcomes.

In addition, cooperation is asymmetric because the distributional consequences of cooperating on governance reforms vary widely for the EU and African governments. The EU and African governments both weigh their decisions to cooperate on governance reforms against the domestic costs and opportunities that this cooperation entails. For the EU, asking African governments to engage in governance reforms only indirectly affects domestic politics within the EU. By contrast, for African governments, cooperation on governance reforms has very direct (and potentially disruptive) consequences for their chances of staying in power. African governments' decision to engage in governance reforms may affect the stability and longevity of their rule. By cooperating with African governments on governance reforms, external actors become closely involved in domestic decision-making processes in African countries (Leininger 2010).

Moreover, EU-Africa cooperation on governance reforms is highly asymmetric, since it is closely linked to the provision of development aid. The EU has operationalised most of its instruments to support governance reforms in Africa within the context of its development policy. Asymmetric interdependence in donor-recipient relations thus allows the EU to inflict direct costs or set financial incentives to leverage in favour of cooperating on governance reforms.

Building on research on EU good governance support and authoritarian regimes, the following sections identify the factors that shape African governments' strategies to engage with the EU in governance reforms. This book argues that African governments' openness to cooperate is influenced by four main factors (Fig. 2.1): first, the EU's good governance strategies - the 'content' and the 'instruments' that the EU 'offers' for cooperation-shape African governments' willingness to engage. Second, African governments' openness to cooperate is influenced by their survival strategies. Third, African governments take into account their interests to engage with the EU 'beyond' governance reforms and notably their 


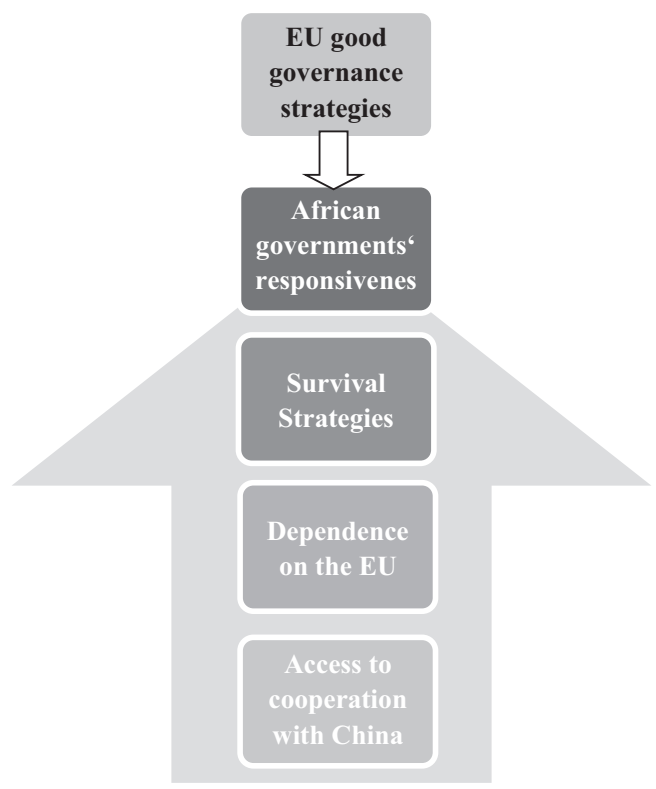

Fig. 2.1 Explaining African governments' response strategies Source: Author's compilation

economic dependence on the EU. Fourth, African governments consider opportunities for cooperation offered by third actors, such as China. The following sections describe each of these factors and their interaction effects in more detail.

\subsection{The EU's Strategies to Promote Governance REFORMS}

To assess the EU's strategies to promote governance reforms in African countries, this analysis builds on research that has analysed the EU's strategies for promoting governance reforms (Börzel and Risse 2009; Wetzel and Orbie 2011; Magen and McFaul 2009; Jünemann and Knodt 2007). I distinguish two dimensions of the EU's good governance strategies. First, the EU may emphasise a different content or substance of good governance and use a different channel to support governance reforms. This part of the framework draws particularly on Börzel et al. (2008a, b). 
Second, I argue that the EU can choose different instruments and thereby promote reforms through either a more conflictive or cooperative strategy.

\section{The EU's Approach: Content and Channels}

The definition of 'good governance' has been intensely debated (KohlerKoch and Rittberger 2006). One can distinguish between a broad and a narrow definition of good governance (Leftwich 1994; Börzel et al. 2008a; Robinson and Hout 2009). Some scholars and practitioners of democracy promotion have adopted the former; the development aid community and researchers working on development policy have initially advocated the latter.

Some scholars adopt a narrow understanding of good governance which is limited to the efficient and effective functioning of the state. They closely associate good governance with the management and performance of the administration and the regulatory framework of the state. Principles such as efficiency and effectiveness, predictability, transparency, accountability, the level of corruption or sound financial management constitute important elements of this understanding (Conzelmann 2003; Faust 2004; Andrews 2013). This narrow definition has been strongly influenced by development policy, and notably by the World Bank (Kaufmann et al. 1999; Fuster 1998). The EU could choose to promote the transparency of decision-making processes, the fight against corruption, the strengthening of public financial management, and civil service and administrative reforms, or it could support the capacities of government institutions to improve the functioning of the administration.

Other authors working in the field of democratisation and external democracy promotion adopt a broader definition with a stronger normative dimension relating to the input dimension of 'good' governance, such as the respect for human rights and democracy (Burnell 2000; Santiso 2003). In their understanding, good governance also entails political aspects, and democratic structures are perceived as key components of good governance. Following this broader understanding, the EU could seek to promote competitive democratic politics, including the strengthening of electoral regimes, political and civil rights, the separation of powers, and horizontal and vertical accountability.

The content of EU good governance policies can be differentiated according to two dimensions of legitimacy formulated by Scharpf (1999) input and output legitimacy. Output legitimacy corresponds to the narrow 
(regulatory) understanding of governance, whereas input legitimacy is equated with the wider (political) concept of good governance predominant in the fields of democratisation and democracy promotion studies.

In addition to the content of EU good governance policies, the EU may use different channels of influence and target state or non-state actors to promote governance reforms. In using the intergovernmental channel, the EU could seek to alter the preferences of the target government to introduce reform processes by manipulating their cost-benefit calculation, or it could aim at changing the target government's preferences for achieving outcomes by socialising them into new norms through processes of social learning and persuasion. The transnational approach, in contrast, seeks to empower non-state actors in relation to their governments (Schimmelfennig 2007).

Combining the different contents and channels the EU may use, this study follows Börzel et al. (2008b), who identify four ideal-type approaches on how the EU can promote governance reforms (Table 2.1). On the one hand, the EU may place stronger emphasis on either input- or outputrelated reform goals. On the other hand, it may either target the intergovernmental channel (state actors) or the transnational one (non-state actors).

The first approach of effective government addresses the intergovernmental channel and seeks to promote output-oriented objectives, focusing on the administrative core of good governance. The EU could seek to improve governance by enhancing the capacities of the government and its administration or by improving the transparency of decision-making processes. The second approach of effective governance also places emphasis on output-oriented reform goals. But it either includes non-state actors in the implementation process to produce better policies by pooling resources and increasing acceptance, or tackles the strengthening of nonstate organisations that help to better implement policies. The third approach of democratic government again relies on the intergovernmental channel. While promoting input-oriented objectives, the EU targets the

Table 2.1 Four approaches of external good governance support

\begin{tabular}{lll}
\hline & Output legitimacy & Input legitimacy \\
Intergovernmental & Effective government & Democratic government \\
Transnational & Effective governance & Democratic governance
\end{tabular}

Source: Börzel et al. (2008b) 
state to make it establish and safeguard a public sphere where interests can be articulated and aggregated. The EU could, for instance, promote civil and political rights by supporting the legal framework or independent state institutions that hold the government accountable. The fourth approach of democratic governance combines the transnational channel with input-oriented reform objectives. In line with this approach, the EU could support the capacities of non-state actors to empower them to improve the democratic quality of decision-making processes and hold the government accountable.

\section{The EU's Instruments: Cooperative or Confrontational Strategy?}

External actors can also seek to impact governance reforms in third countries through different mechanisms and types of instrument. Studies on democracy promotion, external Europeanisation and aid conditionality have suggested various typologies to classify the EU's instruments to promote governance reforms, depending on their different logics of action, mechanisms of influence and different schools of compliance and Europeanisation research (Schimmelfennig and Sedelmeier 2005; Magen and Morlino 2009; Magen and McFaul 2009; Börzel et al. 2008b).

External actors can seek to promote governance reforms through positive or negative conditionality, linking material or non-material incentives to the implementation of governance reforms. Conditionality can be used ex-post (i.e. reductions in development aid in response to deteriorations in governance) or ex-ante (i.e. in the EU enlargement process). External actors may use various forms of political or aid policy dialogues with a view to changing the preferences of the government or non-state actors in the target country through strategies of persuasion and social learning. External actors may seek to support governance reforms by transferring technical and financial assistance to support the human, administrative and financial capacities of state or non-state actors in the target country.

For analytical purposes, and with respect to different underlying mechanisms of influence and logics of action, the literature on EU external governance and democracy promotion generally differentiates between conditionality, dialogue and aid, and often analyses only one of them, for instance the impact of democracy aid on political reforms. In practice, however, external actors generally combine these instruments in different ways. The EU's instruments can respectively be conceived on a continuum ranging from a 'confrontational' to a 'cooperative-rewarding' strategy (Fig. 2.2). 


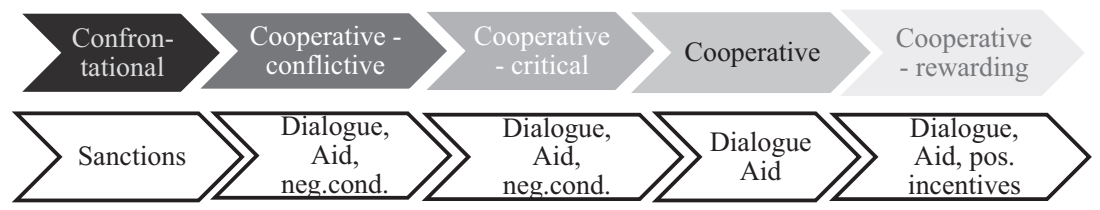

Fig. 2.2 The EU's good governance instruments: between confrontation and rewards

Source: Author's compilation

At one end of the spectrum, external actors can adopt a confrontational strategy and merely rely on aid, trade or other forms of sanctions, for instance in response to serious violations of human rights or a coup d'état.

Beyond a confrontational strategy and the usage of sanctions, external actors can combine dialogue, governance aid and conditionality in various ways. A cooperative strategy can take different forms, depending on the combination of dialogue, technical and financial assistance, and conditionality that external actors choose. In the case of a cooperative-conflictive strategy, the EU would combine governance aid and dialogue with strong negative incentives such as budget-support suspensions to exert pressure on the target government. In the case of a cooperative-critical strategy, the EU would combine aid and dialogue with smaller 'sticks' such as critical public statements (shaming) or withholding governance aid to exert pressure on the government. External actors could decide to adopt a purely cooperative strategy and rely merely on dialogue and governance aid to promote reforms. Finally, the EU could adopt a cooperative-rewarding strategy and combine dialogue and governance aid with positive incentives ('carrots'), such as affirmative public statements or aid modalities such as budget support.

Combining the EU's 'approach' and its 'instruments' allows us to develop a comprehensive framework to analyse the EU's strategies to support governance reforms in individual African countries and over time. The EU could choose to put a strong emphasis on promoting either a narrow or a comprehensive governance agenda. It could choose to merely work with governments or to empower non-governmental actors $v i s-\grave{a}$-vis the government. In addition, the EU could choose not only to rely on dialogue and governance aid but also to combine these instruments with positive or negative incentives to foster an active cooperation on governance reforms. The costs and benefits that the narrow or comprehensive 
agenda entail for African governments would thus be exacerbated by the EU's usage of confrontational or rewarding governance instruments.

\subsection{African Governments’ Responsiveness}

African governments can respond to the EU's strategies in different ways. First, with regard to the content or substance of the EU's approach, African governments may be more or less willing to engage in a comprehensive or narrow governance agenda. In cases where the EU seeks to promote output- as well as input-related reforms, African governments may be willing to cooperate on a comprehensive agenda, they may be willing to engage only in reforms that improve the effectiveness of government institutions or they may not be willing to cooperate with the EU on governance reforms at all. African governments could be more or less willing to accept EU support for non-state actors and the EU's usage of the transnational channel. Second, African governments can choose to adopt different strategies towards different types of instrument that the EU seeks to employ. For instance, governments may be willing to engage in dialogue (political dialogue or aid policy dialogues), they may be willing to commit to concrete governance reform objectives in exchange for material incentives (positive conditionality), but they may not be willing to cooperate on the implementation of governance aid or vice versa.

African governments' responsiveness towards EU good governance instruments can be conceived on a continuum, ranging from active and willing engagement to indifference. Classifying 'indifference' is relatively straightforward and would entail that African governments do not engage in dialogue, would not agree to implement governance aid and do not comply with EU conditionality. In the case of indifference, African governments would not be willing to engage either in a broad or narrow governance agenda. It is more difficult, however, to discern different forms of 'cooperativeness'. For reasons of simplicity, the analysis will distinguish between reluctant and active cooperation. Active cooperation would entail that African governments are willing to cooperate with the EU on the entire governance agenda that the EU seeks to promote and across all governance instruments that it seeks to apply. Reluctant engagement would entail that governments are willing to engage with the EU only in parts of the agenda that the EU seeks to promote and only in some of the cooperative instruments that the EU applies. 


\section{Interaction Effects: EU Good Governance Strategies and African Governments' Responsiveness}

The study starts off with a simplified assumption that cooperation on governance reforms is costly for African authoritarian regimes. External support for governance reforms is generally assumed to promote political liberalisation and thereby potentially challenges the propensity of African governments to persist in power (Wright 2009; Cornell 2012). Against this background, one would expect that the more the EU promotes a broad 'content' that seeks to support not only the effectiveness of decisionmaking processes but also their democratic quality and the more the EU seeks to empower non-state actors in holding the government accountable, the less willing African governments should be to engage with the EU. Further, the more the EU puts pressure on African governments and uses a conflictive approach to support reforms, the less willing African governments should be to engage with the EU.

EU-Africa cooperation on governance reforms is an interactive and iterative situation (Table 2.2). Thus, if the EU narrows or broadens its good governance approach over time, we would expect that governments in African authoritarian regimes become more or less willing to cooperate. For instance, if the EU decides to broaden its approach from a narrow to a comprehensive governance agenda, African governments should become less willing to engage, as reforms geared towards democratic government and governance generate more costs for authoritarian regimes. If the EU narrows its approach and promotes mainly effective government, African governments would be expected to become more willing to engage with the EU since effective government institutions may also be in the interest

Table 2.2 Interaction effects between EU good governance strategies and African governments' response

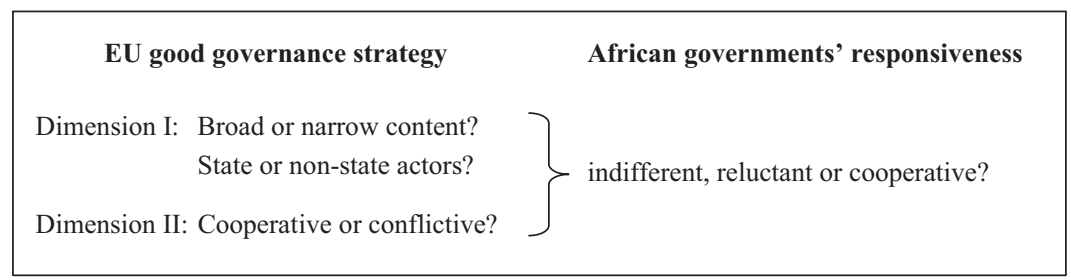

Source: Author's compilation 
of African authoritarian regimes. Similarly, if the EU decides to adopt a more conflictive strategy and uses negative conditionality, this should prompt African governments to become more reluctant to engage with the EU. If the EU decides to adopt a more cooperative strategy and to provide positive additional rewards to the governments, this should induce them to become more willing to engage with the EU.

The EU's good governance strategies are only one factor that shapes African governments' willingness to cooperate on governance reforms. In order to develop more specific assumptions on the conditions under which governments are willing to engage, we therefore need to open the 'black box' of domestic politics of African authoritarian regimes.

\subsection{Survival Strategies of Governments in Dominant PARTy Regimes}

When deciding if they want to cooperate, African governments assess the costs and benefits that the EU's offer entails. Political leaders in dominant party regimes are conceived as rational and self-interested actors seeking to maximise their chances of remaining in power (not too different from their counterparts in democracies). The threat of losing power, and opportunities to increase their chances of staying in power, is thus the basic factor that motivates authoritarian governments to cooperate with the EU on governance reforms. Understanding the costs they want to avoid and the benefits they seek helps to explain their openness to engage with the EU.

\section{Survival Strategies}

Autocratic leaders do not remain in office through competitive elections, where they would need to secure support from the majority of the electorate. They therefore always fear being ousted. Put simply, domestic politics in authoritarian regimes can be conceived as a political 'game' between the leadership, members of the ruling coalition (i.e. the ruling party and the military) and the broader society (Bueno de Mesquita et al. 2003). Dominant party regimes have a relatively broad ruling coalition, compared to other autocracies. Whereas military regimes primarily rely on the military, or monarchies on the royal family, political leaders in dominant party systems, instead, have to secure support from members of the ruling party, the military and security forces, and sometimes also strategic business sectors. 


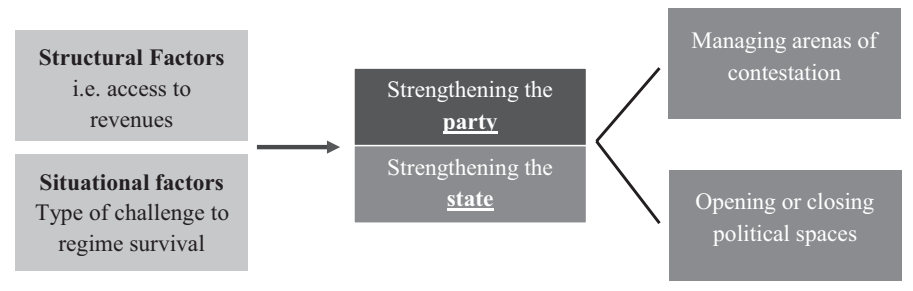

Fig. 2.3 African governments' survival strategies meet EU good governance strategies

Source: Author's compilation

Political leaders in dominant party regimes have at least three basic strategies at hand to increase their chances of retaining power. They can invest in strengthening party or state institutions. They can use arenas of political contestation such as elections or parliaments to mobilise support. They can rely on coercion to open or close political spaces (see Fig. 2.3 for an overview). Research on authoritarianism often examines only one of these strategies and investigates variation across different types of authoritarian regimes. The objective here is to bring these three strategies together and to specify them for dominant party systems.

\section{The Foundation of Political Survival: Strengthening the Party or the State}

Political leaders in dominant party systems need strong states or strong parties. Strong state institutions or strong parties are instrumental in effectively managing arenas of contestation and opening and closing political spaces to increase their chances of staying in power. Political leaders in dominant party regimes can decide to particularly invest in building strong political parties, they can invest in building strong states or they can use a mixture of the two. In dominant party systems, the ruling party often fuses with formal state institutions. Ruling parties may almost substitute state functions or vice versa. Those political leaders that have neither strong ruling parties nor strong states are often quickly removed (Levitsky and Way 2010).

Recent research on autocratic regimes has often focused on the role of the ruling party in enhancing regime stability. Political parties in authoritarian regimes provide mechanisms to manage leadership succession (Geddes 2006) and intraelite conflicts (Brownlee 2007). They allow for distributing spoils to regime supporters (Magaloni 2006) and coercing 
opponents. Moreover, political parties help to develop a support base that the political leadership can mobilise, for instance in case of popular uprising (Geddes 2006). Via access to financial revenues, career opportunities or other perks, the party gives its members a stake in the regime. Through trade unions, youth and women's organisations or cooperatives, wellinstitutionalised ruling parties extend their influence to a large segment of society (Geddes 2006; Magaloni 2006). Empirical studies suggest that these institutional mechanisms make dominant party regimes more durable than other forms of authoritarian regimes such as monarchies or military regimes (Smith 2005; Geddes 2006; Svolik 2012). Those regimes with relatively strong political parties are found to be most durable (Smith 2005 ) and often among those economically most successful (Bueno de Mesquita et al. 2003; Faust 2007; Gehlbach and Keefer 2011).

Autocrats can also decide to invest in state institutions. Strong states are one essential factor in securing the stability and longevity of authoritarian rule (Huntington 1969; Levitsky and Way 2010, 57). Authoritarian state institutions may help governments to effectively coerce and repress political opponents. Governments invest in the security apparatus and boost capacities of the army, the police, paramilitary forces or intelligence services. According to Levitsky and Way (2010), the cohesive capacity of authoritarian states, defined as the level of compliance within the state apparatus and the reach of the state, is critical to effectively using coercion. Furthermore, governments also use state institutions as an instrument to provide public goods or to coopt regime opponents. Political leaders may decide to strengthen public administration and the effectiveness of bureaucracies, raise domestic revenues, and improve public goods provision. Modern, rational-legal and meritocratic bureaucracies in the Weberian sense allow for effectively formulating and implementing policies needed to generate economic growth, raise taxes or develop effective healthcare and education systems. On the other hand, governments may use state institutions to distribute perks and spoils. Regime opponents may be coopted by granting access to positions in the government administration. Political leaders may use state institutions to provide spoils to their support group, for instance, their ethnic group or people from their home town.

\section{Managing Political Survival: Effectively Controlling Arenas of Contestation Such as Elections, Parliaments and Courts}

Dominant party regimes are not fully closed, but allow for some (albeit limited) political contestation. They establish formal democratic institutions such as elections, parliaments or courts that strongly resemble their 
equivalents in democratic regimes. Even though these institutions fulfil different functions than in democratic regimes, effectively managing arenas of contestation is important for incumbents to secure their position in power (Gandhi and Przeworski 2007; Gandhi 2008; Schedler 2009).

Elections are probably most important in this regard. Even though elections in authoritarian regimes are not free and fair, winning elections with a high voter turnout and an overwhelming majority is vital for political leaders (Magaloni 2006). Elections constitute important points in time when opponents inside or outside the ruling elite can directly challenge the incumbent. Opposition parties may seek to mobilise mass movements, for instance if they identify underlying schisms within the ruling elite that they can exploit (Brownlee 2007). Defecting members of the ruling party may decide to use elections to openly challenge the incumbent, for instance during periods of economic crisis (Reuter and Gandhi 2011). In addition, elections allow incumbents to enhance regime stability. Overwhelming electoral victories signal to regime supporters that it pays off to remain loyal to the leadership as the opposition presents no viable alternative. Overwhelming victories also signal to regime opponents that their chances of gaining power are limited (Magaloni 2006, 7ff; Magaloni and Kricheli $2010,129 f)$. Moreover, election results give some indication about the popular support of the ruling party and about the regional and social distribution of its support base, allowing it to reward supporters with access to government funds and to punish defectors by restricting access to spoils (Magaloni 2006, 9). Political leaders may therefore decide to invest heavily in election campaigns.

Beyond elections, governments in dominant party regimes may decide to use parliaments to solicit cooperation from the ruling party and reduce threats from opposition outside of the ruling elite (Gandhi and Przeworski 2007). Parliaments may provide a forum for the government to grant policy concessions to opposition groups in exchange for regime support (Gandhi and Przeworski 2007). Parliamentary seats may also be allotted to secure the support of members of the ruling elite. Political leaders in autocratic regimes may further invest in the judiciary to promote their interests. Moustafa and Ginsburg $(2008,4)$, for instance, show how courts are used to strengthen social control and sideline regime opponents: they may be used to promote 'legal' legitimacy; they may facilitate trade and investments; and they may improve compliance of the bureaucracy and elite cohesion. 


\section{Managing Political Survival: Opening and Closing Political Spaces}

Authoritarian leaders rely on different forms of coercion to open or close political spaces (Wintrobe 2001). Coercion is used as an instrument of sanction against individuals or organisations to reduce threats from the opposition and reinforce their grip on power (see Davenport 2007, for an overview). Following Levitsky and Way (2010) one can distinguish between 'high-intensity' and 'low-intensity' coercion. Dominant party systems are generally found to be less likely to use repression than other types of authoritarian regimes since they depend more strongly on the loyalty of broader segments of society (Davenport 2007; Escribà-Folch and Wright 2015).

Dominant party regimes can be expected to use high-intensity coercion to respond to mass protests and challenges from the opposition outside of the ruling elite. Prominent examples of high-intensity coercion would include the killing of protesters in Tiananmen Square in China, in 1989, or more recently in Tahrir Square in Egypt. High-intensity coercion is costly for authoritarian regimes, both economically and politically (Wintrobe 2001; Conrad 2011). It may have medium-term negative effects on economic development as citizens refuse to engage in economic activities and international investments decline in a politically insecure environment (Bueno de Mesquita and Smith 2010). In addition, highintensity coercion requires autocrats to substantially invest in the security forces to secure their loyalty (Wintrobe 2001). Dominant party regimes would be expected to use high-intensity coercion as a measure of last resort only in situations when the leadership is in a particularly insecure position, facing very strong challenges from the opposition.

By contrast, dominant party regimes can be expected to generally rely on low-intensity coercion to gradually close political spaces. Low-intensity coercion can take various forms. Authoritarian regimes may use a variety of formal and legalised or informal strategies to intimidate and harass civil society organisations, and reduce the freedom of the media, opposition parties or individual regime critics (Davenport 2007; Levitsky and Way 2010). Lowintensity coercion may be targeted directly at defecting members of the elite in order to limit their chances of challenging the incumbent. For instance, anticorruption campaigns may be used to marginalise party members who foster a split in the party. On the other hand, low-intensity coercion may be targeted at the broader society to limit the opportunities of defectors to mobilise mass support. For instance, if former party members seek to challenge the incumbent at the ballot box, reductions in press freedom and 
spaces for opposition parties to campaign may limit the ability of defectors to mobilise support. If low-intensity coercion is successful, it reduces the need to rely on high-intensity coercion (Levitsky and Way 2010).

\section{Structural and Situational Factors That Impact on the Choice of Survival Strategies}

Several factors influence political leaders' decisions to use a specific type of strategy to increase their chances of remaining in power. Structural factors constrain the basic choices of political leaders to rely on a certain strategy. For instance, strong parties emerge only under very specific circumstances: conditions related to the founding moment of the regime may considerably shape the incentive for political leaders to invest in party building (Brownlee 2007; Smith 2005). The presence (or absence) of access to easy revenues from natural resources is found to affect the willingness of political leaders to invest in strong parties and effective states (Smith 2005; Ross 1999) and to use coercion and cooptation. Moreover, research on East Asian developmental states has illustrated that not only does access to revenue shape the willingness of political leaders to invest in strong states, but the presence of external security threats has also been identified as a necessary condition for strong state institutions to emerge (Doner et al. 2005).

Furthermore, a leadership's political survival can be challenged by situational factors. Notably, opponents from outside or inside the ruling elite can confront the incumbent at a specific point in time. Challenges to regime survival constitute defining moments in the life of ruling parties and can induce substantial changes in survival strategies (Reuter and Gandhi 2011; Conrad 2011). First, political leaders can be under threat from groups outside of the ruling elite, such as opposition parties and mass movements (Ulfelder 2005; Geddes 2006; Gandhi and Przeworski 2007). In Africa, for instance, mass movements and civil society protests played an important role in regime liberalisations and transitions in the late 1980s and early 1990s (Bratton and Van de Walle 1997). Second, persons inside the ruling elite, such as individual members or factions of the ruling party, can decide to defect and to challenge the leadership by presenting themselves as a political alternative (Magaloni 2006; Reuter and Gandhi 2011; Svolik 2012). Finally, officials of the party or security forces may decide to defect without directly attempting to challenge the leadership. If that happens, it signals that the regime is weak, possibly prompting further erosion of the support coalition, which may eventually result in mass mobilisation and opposition. 
In summary, governments in dominant party systems can decide to invest in the party or the state. They need to control arenas of contestation and can decide to open or close political spaces to strengthen their grip on power. Strong state institutions or strong ruling parties are instrumental for governments in dominant party systems to effectively manage arenas of contestation and use coercion to open or close political spaces (Fig. 2.3). Whether the government decides to invest more strongly in the state or in the party and how it uses arenas of contestation and coercion is influenced by a set of structural and situational factors.

\section{EU Good Governance Strategies Meet Dominant Party Regimes}

We assume that cooperation on governance reforms can generate costs as well as benefits for authoritarian governments. Depending on which survival strategies governments use, EU demands to engage in governance reforms can converge or diverge with authoritarian governments' preferences. The size of the costs and benefits that cooperation involves can vary significantly across countries and over time.

This basic proposition that cooperation on governance reforms can generate not only costs but also benefits contrasts with some of the research on good governance support. Some start by assuming that the implementation of governance instruments mainly entails costs for authoritarian governments. Studies that focus on the 'input dimension' of good governance and analyse, for instance, the effect of democracy aid on political reforms usually start by assuming that democracy aid fosters political liberalisation and thereby entails costs for the target government (Wright 2009). Governments in relatively stable authoritarian regimes with good chances of remaining in power are then expected to accept some democracy aid as they can afford higher levels of political liberalisation without losing power (Cornell 2012). Moreover, studies focusing on the 'output dimension' of good governance argue that most target governments accept aid geared towards promoting effective institutions merely as 'signals - to garner short-term support from the international community' (Andrews 2013, 215). Governments' interest in receiving development aid, rather than a genuine interest in engaging in governance reforms is identified as the main driver for cooperation (Andrews 2013).

The previous section developed a comprehensive picture of possible survival strategies. African governments' cooperation with the EU on governance reforms touches only upon parts, but not all, of these strategies. 
Recall from Sect. 2.1 that EU good governance strategies are directed towards supporting the effectiveness of government institutions or the democratic quality of decision-making processes; moreover, the EU can strengthen the capacities of non-state actors or empower them in holding the government accountable. Cooperation with the EU on the implementation of governance instruments may therefore be relevant for (a) building strong and effective state institutions; (b) managing arenas of contestation such as elections, parliaments or courts; and (c) open or close political spaces (Fig. 2.3). On the other hand, since the EU mainly engages with African governments and the state more broadly, the EU's good governance strategies have limited relevance for political leaders' decisions to build strong ruling parties. Under what conditions does cooperation with the EU on governance reforms then involve costs or benefits for authoritarian governments (Table 2.3)?

Table 2.3 The costs and benefits of cooperating on governance reforms

\begin{tabular}{ll}
\hline Survival strategies & $\begin{array}{l}\text { Costs and benefits of } \\
\text { cooperation }\end{array}$
\end{tabular}

\section{Building effective states}

The more governments use and invest in strengthening state institutions to generate economic growth and provide public goods...

The more governments use formal state institutions mainly to distribute private goods and spoils....

\section{Managing arenas of political contestation}

The more governments are confident about winning elections without significant fraud...

The more governments are afraid of facing challenges from the opposition during elections...

III. Opening or closing political spaces

The more governments decide to open political spaces to prevent opposition challenges...

The more governments decide to use low-intensity coercion to gradually close political spaces to prevent opposition challenges...

The more governments decide to use high-intensity coercion to close political spaces to respond to imminent threats to regime survival...

...the higher the benefits to cooperate with the EU

...the higher the costs to cooperate with the EU

...the higher the benefits to cooperate with the EU ...the higher the costs to cooperate with the EU

...the higher the benefits to cooperate with the EU ...the lower the costs to cooperate with the EU

... the higher the costs to cooperate with the EU 


\section{Building Effective States}

For governments that decide to invest in building effective states geared towards promoting economic growth and public goods provisions, cooperation with the EU on governance reforms can be beneficial. Cooperating with the EU may help governments to improve access to domestic tax revenues or to make policy formulation and implementation more effective. EU support for public administration and civil service reform, public financial management and the rule of law are thus expected to resonate well with the preferences of the government. Moreover, even EU assistance to strengthen capacities of non-state actors that support the government in providing basic public services can converge with the government's preferences.

By contrast, authoritarian regimes that have limited interest in building effective states, because they mainly use the state to distribute rents and spoils, have few incentives to cooperate with the EU on governance reforms. EU support geared towards improving the transparency of public finances, anticorruption policies and civil service or public administration reforms run counter to the government's attempts to use government institutions to distribute spoils. In these cases, cooperation with the EU on governance reforms is thus expected to be costly.

\section{Managing Arenas of Political Contestation}

EU support geared towards elections, parliaments or courts may also entail costs or benefits. Cooperating with the EU may bolster the external legitimacy of the authoritarian regime ${ }^{1} \mathrm{EU}$ technical assistance may help African governments to actually conduct elections. However, EU assistance may also be exploited by the opposition and bolster its position vis$\grave{a}$-vis the government.

One would expect that the type of challenge to regime survival that the government faces ahead of elections is an important factor that mitigates the size of the costs and benefits that cooperation entails, and thus African governments' interests in engaging with the EU on elections. Governments that face little challenge from opponents and that can win elections overwhelmingly and relatively easily without resorting to significant fraud are likely to have an interest in cooperating with the EU. In these cases, EU technical assistance may provide important benefits to support the election process: EU public statements after the elections or findings from election observation missions may boost domestic and international legitimacy. In contrast, in cases where the 
opposition or defecting members of the elite use elections to directly challenge the ruling party, cooperating with the EU may be costly. The EU's critical public statements and its technical assistance to support the media or civil society to monitor the election campaign and election process may be exploited by the opposition and used to further challenge the incumbent.

\section{Opening or Closing Political Spaces}

For governments that decide to open or close political spaces, cooperating with the EU on governance reforms may also generate costs and benefits. Cooperation with the EU is likely to accrue some benefits in cases where governments decide to open political spaces to strengthen input legitimacy. The EU may extend technical assistance needed, for instance, to support the media or civil society organisations. Cooperation with the EU may provide additional external legitimacy during periods of political openings.

Instead, for governments that decide to use high- or low-intensity coercion to close political spaces, cooperation with the EU on governance reforms is expected to generate costs. However, the size of these costs varies depending on the measures governments use and the type of challenge to regime survival that authoritarian governments face.

In situations where governments use high-intensity coercion to counter mass opposition, engagement with the EU in governance reforms is costly and the government is least likely to engage. In case of mass opposition, even small steps towards liberalisation and ceasing coercive measures may immediately threaten regime survival. In this context, engaging with the EU in political dialogue, the implementation of governance aid or other EU instruments geared towards supporting governance reforms would be particularly risky for the government.

In cases where governments use low-intensity coercion to respond to party splits or reduce challenges from defecting members of the ruling elite, cooperation on governance reforms with the EU is also risky. Yet, engagement in governance reforms is less challenging here than in cases of mass mobilisation. Finally, if members of the ruling elite defect but do not choose to openly challenge the leadership, the government has more leeway to engage with the EU in governance reforms. While erosion of the ruling elite may signal that the regime is weak, only in the medium- to long-term may opponents seek to exploit this weakness, run in elections themselves, align with opposition groups and mobilise mass opposition. 


\subsection{African Economic Dependence on the EU}

The higher the costs of engaging with the EU in governance reforms, the more African governments take into account their dependence on the EU when deciding if they want to cooperate with the EU. African governments' dependence on the EU is shaped by their vulnerability to EU pressure and actions taken by the EU. According to Keohane and Nye's (1987) seminal definition, 'dependence means a state of being determined or significantly affected by external forces'.

African governments thus weigh costs stemming from the implementation of governance instruments against benefits offered by the EU in the form of development aid or trade and investments. Moreover, they assess how vulnerable the EU is to actions taken by them. The more dependent African governments are on the EU, the more likely they are to cooperate. The less dependent African governments are on the EU, the less likely they are to cooperate if this entails risks for regime survival. While this argument is relatively straightforward, the more difficult (and largely empirical) question is to define how dependent African countries are on the EU.

\section{Dependence on Aid and Other Official Flows}

If the EU provides important volumes of external finance, African governments may be willing to engage in governance reforms, even in cases where these reforms are costly. The higher the government's dependence on development aid as a source of domestic revenue and the higher the EU's share in total aid flows to the country, the more willing the government should be to engage with the EU.

African governments may use development aid and loans to divert them to regime supporters. Development aid allows the government to free its own resources and to use them to coopt strategic groups or to avoid taxation of those societal groups that are important for the government to remain in office. Empirical studies find, for instance, that foreign aid increases government spending while reducing government revenue and efforts to raise taxes (Remmer 2004). All types of foreign aid affect the opportunity costs of autocratic leaders to modify the allocation of their own resources. Regardless of whether or not aid is channelled through projects or direct budget support, it is a form of external finance that frees up government resources. Governments can (but do not necessarily do) use these resources to coopt regime opponents. 
We need to add several points to this basic picture. African governments assess the short- and longer-term benefits of cooperating with the EU. First, some aid modalities give the government considerably more discretionary power to allocate resources according to its preferences. The government's propensity to free domestic resources in case the EU or other donors provide food aid is considerably lower than in the case of direct budget aid, at least in the short-term. Second, some forms of aid and sectors to which aid is allocated may be much closer to the government's preferences than other sectors, freeing up more domestic resources in the short-term. Third, if the EU decides to stop or withhold development aid, the costs for the African government differ depending on the modalities by which aid is provided. For instance, withholding budget support funds that the government uses to pay the salaries of civil servants may be more detrimental in the very short-term than withholding project aid allocated to constructing rural roads.

\section{Dependence on Trade and Investments}

Access to trade and investments set direct and more indirect incentives for African governments to cooperate with the EU. For many African countries, trade taxes account for a large share of overall tax revenues. African governments have often maintained a strong control over strategic export sectors. In addition, many African countries still have only very few export commodities, and their export markets are not very diversified (Di John 2010). The EU as a whole has been the largest trading partner for many countries. Trade with the EU may generate important tax revenues for African governments or revenues for societal groups whose support is particularly important for the government. If export goods cannot easily be shifted to other markets, the vulnerability of the government to potential actions taken by the EU is high.

In addition to trade, direct investments may have direct and more indirect effects. They have an indirect effect if they help to promote economic growth, giving the government more resources that it can use to buy support. If the population associates economic growth with the government, this boosts its legitimacy. Direct investments may also have more direct effects. Investments in strategic sectors, for instance resource extraction, increase government revenues. Direct investments may also create important sources of income for societal groups on which the government relies to remain in power. Foreign direct investments in Africa have been small 
Table 2.4 How economic dependence on the EU affects African governments' willingness to cooperate on governance reforms

\begin{tabular}{llll}
\hline & \multicolumn{2}{c}{ Dependence on aid and other official flows } \\
\cline { 2 - 3 } & \multicolumn{2}{c}{ High } & \multicolumn{1}{c}{ Low } \\
\hline $\begin{array}{l}\text { Dependence } \\
\text { on trade and } \\
\text { investments }\end{array}$ & High & $\begin{array}{l}\text { Incentive to cooperate on } \\
\text { governance reforms is high }\end{array}$ & $\begin{array}{l}\text { Incentive to cooperate on } \\
\text { governance reforms is medium } \\
\text { Incentive to cooperate on } \\
\text { governance reforms is low }\end{array}$ \\
\hline & $\begin{array}{l}\text { Incentive to cooperate on } \\
\text { governance reforms is } \\
\text { medium }\end{array}$ & \\
\hline
\end{tabular}

Source: Author's compilation

compared to other regions, but European and North American companies have traditionally been the major sources of direct investments (AfDB, OECD and UNDP 2016, 52ff). The dominance of European companies has been particularly pronounced in some (often resource-rich) countries, often as a result of colonial ties.

We can conclude that through aid, trade and investments, the EU potentially has a strong leverage to set incentives for African governments to cooperate on governance reforms (Table 2.4). The higher the economic dependence on the EU, the more likely the government is willing to engage in governance reforms. However, some notes of caution need to be sounded. All other things being equal, countries that depend on the EU in terms of aid but not trade and investments may have much stronger incentives to cooperate with the EU on governance reforms than countries that depend on the EU in terms of trade and investments but not aid. Empirical evidence suggests that the EU does not condition access to aid and trade in similar ways to governance reforms. For instance, the Cotonou Agreement allows the EU to suspend aid and trade preferences in case of fundamental human rights violations or disrespect of democratic principles (Article 96 of the Cotonou Agreement). Yet, in practice, the EU has mostly used the suspension of aid rather than trade to sanction a breach of the essential element clause Portela (2010).

\subsection{The Rise of China: What Effect?}

What happens if China becomes a major partner for African countries? Similar to their cooperation with the EU, governments in dominant party regimes also define their interests in engaging with China taking into 
Table 2.5 Cooperation with China: what effect on African governments' willingness to cooperate on governance reforms?

\begin{tabular}{llll}
\hline & & \multicolumn{2}{c}{$\begin{array}{r}\text { Does cooperation with China reduce economic } \\
\text { dependence on the EU? }\end{array}$} \\
\cline { 3 - 4 } & & \multicolumn{1}{c}{ Yes } & No \\
\hline China engaging in & Yes & Strong effect & Medium effect \\
survival strategies? & No & Medium effect & No effect
\end{tabular}

Source: Author's compilation

account their domestic survival strategies. Economic cooperation with China may reduce African governments' dependence on the EU and thus shape African governments' incentives to cooperate with the EU on governance reforms. China may also offer to cooperate with African governments on shaping their survival strategies, which may equally affect their willingness to engage with the EU (see Table 2.5 ). China is obviously only one of the emering powers and its engagement with African countries is part of a broader power shift. However, China is by far the most important actor in terms of its economic weight and it is the only actor that potentially provides an alternative development model.

\section{Cooperating with China: Reducing Economic Dependence on the EU?}

The basic argument on how the rise of China shapes African governments' openness to engage with the EU in governance reforms is again relatively straightforward. China may provide African governments with access to additional sources of development aid, official flows, trade and investments, thereby reducing the vulnerability of African governments to EU pressure. The more that cooperation with China reduces African countries' economic dependence on the EU, the less likely African governments are to engage with the EU in governance reforms. The much more difficult issue is assessing how and to what extent China affects African governments' dependence on the EU. To measure the relevance of China compared to the EU, one needs to compare the structure of European and Chinese cooperation with African countries against the background of the domestic incentives for African countries to cooperate with the EU and China.

The extent to which aid and official flows from China reduce African governments' dependence on EU aid hinges on several factors. The first 
factor is the size of Chinese official flows. All other things being equal, one can assume that the more a country has access to official flows from China, the less the African government is willing to cooperate with the EU on governance reforms. The modalities through which official flows are provided and the sectors to which they are provided are a second factor shaping African governments' willingness to engage with the EU. The more China's official flows match the preferences of African governments in terms of modalities and sectors to which they are provided, the less likely the government is to cooperate with the EU. Lastly, the timing of when China starts providing substantial official flows to African countries should have an impact on African governments' vulnerability to EU pressure. If China provides important volumes of official flows at a point in time when the EU attempts to use development aid funds to put pressure on African governments, they can be expected to be less willing to comply with EU demands.

Similarly, the extent to which access to Chinese trade and investments reduces African countries' dependence on the EU depends on the scale and structure of economic cooperation. The diversification of export markets and the opening of markets for new export goods as a result of access to trade with China impact on African governments' interests in cooperating with the EU. Growing trade with China may provide significant windfall profits for African governments. Cooperation with China may create business opportunities for societal groups whose support is crucial for African governments to remain in power.

In addition, if China significantly increases its direct investments in African countries, this may create opportunities for countries that have previously had very little access to foreign direct investments. Or it may diversify sources of direct investments and reduce the dominance of European companies.

\section{China: Alternative Support for Survival Strategies?}

African governments analyse the benefits and costs of cooperating with the EU on governance reforms not only in light of their economic dependence on the EU and potential shifts in dependence due to access to cooperation with China. African governments also take into account alternative offers to engage in their survival strategies. The Chinese government does not embrace the promotion of 'good governance' as an objective in its external relations. In contrast, its foreign policy discourse highlights principles of non-interference, projects a traditional understanding of national 
sovereignty and explicitly rejects the promotion of a development 'model'. Yet, China might still engage with African governments in their survival strategies because of China's own economic and political interests or in response to requests from African governments.

As in the case of cooperation with the EU, African governments assess how cooperation with China fits with their domestic survival strategies. Recall the panoply of strategies and institutions that governments in African dominant party regimes can use to secure their position in power (Sect. 2.3). The Chinese government could provide assistance that resembles EU good governance strategies and targets similar dimensions of African governments' survival strategies as the EU. China could, for instance, assist in improving the capacities and effectiveness of government institutions through training courses or supplying office equipment. China's economic interests may lead the Chinese government to provide technical assistance to address some of the side effects stemming from growing economic interdependencies with African countries. For example, growing Chinese investments may prompt a closer engagement with anti-corruption bodies or support to African countries' regulatory frameworks.

On the other hand, China could also engage with African governments on elements of their survival strategies that the EU does not target. In contrast to the EU, China may engage with African ruling parties. Some have argued that the introduction of inner-party checks and balances, the institutionalisation of leadership succession and perfomance-based incentive systems for party cadres constitute important factors that contributed to sustained economic growth in China (Keefer 2007; Zhao 2010; Gehlbach and Keefer 2011). Despite numerous differences between the Chinese Communist Party (CCP) and African ruling parties, cooperation on inner-party reforms might still be very attractive. Particularly for those African political leaders who seek to substantially invest in reforming and strengthening their ruling parties, China could become an interesting cooperation partner. For China, party-to-party cooperation may be interesting from a political as well as economic perspective. High-level visits by party officials can be one instrument to intensify political relations, for example, with those countries where economic cooperation is limited. Regular dialogue between ruling parties may give important insights into domestic political dynamics in African countries. Party-to-party relations may also open channels to establish and promote business relations.

Very little research exists on China's cooperation with African governments that relates to these governments' survival strategies. Two preliminary propositions can be made. First, the stronger the Chinese economic 
and political interests in cooperating with individual African countries, the more likely China is to engage with African countries in elements of their survival strategies - either by request of the African government or to ease growing economic interdependencies. Second, the more the Chinese experience with economic and political reforms 'resonates' with African domestic contexts and African governments' survival strategies, the more China's support affects African governments' willingness to cooperate with the EU on governance reforms.

\subsection{Map of the Puzzle: Explaining African Governments' ResponsIVENESS}

African governments face some tough choices when deciding whether they want to engage with the EU in governance reforms, or not. Drawing the points from this chapter together, we can start to build a picture on the factors influencing African governments' decision to engage with the EU.

First of all, African governments' decision is influenced by the EU's good governance strategies. More specifically, the content or substance of what the EU seeks to promote as part of its good governance agenda and the instruments the EU uses, both shape African governments' willingness to cooperate on governance reforms. Second, African governments weigh up the costs and benefits that cooperation with the EU entails against their chances of remaining in power. The more the EU's offer for cooperation aligns with the domestic survival strategies of African governments, the more likely they are willing to cooperate and vice versa. Third, African governments analyse the costs resulting from their engagement in governance reforms against other benefits of cooperating with the EU. If the EU offers comprehensive and attractive packages of aid and trading opportunities to African countries, African governments may still be willing to engage with the EU in governance reforms, even if this engagement bears certain risks for regime stability. Fourth, African governments do not take their decisions to cooperate with the EU in isolation. Instead, they assess opportunities of engaging with the EU in light of cooperation opportunities provided by other international actors such as China. If China becomes an alternative cooperation partner, reducing African countries' economic dependence on the EU and providing attractive support for African governments' survival strategies, we would expect that African governments become less likely to engage with the EU in governance reforms.

EU-Africa cooperation on governance reforms is an interactive and iterative situation. In this regard, changes in one or several of the four 
main variables over time are expected to result in changes in African governments' openness to engage. For instance, if the EU decides at a specific point in time to broaden the content of its good governance strategy, African governments may become less willing to cooperate. If African governments' survival strategies shift, for example, in response to substantial threats from the opposition, this may reduce their willingness to engage. Finally, changes in African governments' dependence on the EU and changing access to cooperation with China over time may also affect African governments' willingness to engage in governance reforms.

The aim of this book is to explain differences in African governments' openness to engage with the EU in governance reforms by exploring interaction effects between the EU's good governance strategies, the survival strategies of African governments, their dependence on the EU and the rise of China as an alternative cooperation partner.

The following three chapters all proceed in a similar way. For each country case, between two and four time periods are distinguished, depending on whether the EU has modified its good governance strategies in that country. For each time period, the chapters analyse the interaction of the four main variables. The main objective of the within-case analysis is to explain why the responsiveness of the Angolan, Ethiopian or Rwandan government towards EU demands to engage in governance has varied over time. In addition, the case studies use cross-case comparisons to further investigate the relative explanatory power of the four main variables.

\section{Notes}

1. See, for instance, Simpser and Donno (2012) for a discussion on the unintended side-effects of election monitoring.

Open Access This chapter is licensed under the terms of the Creative Commons Attribution 4.0 International License (http://creativecommons.org/licenses/ by $/ 4.0 /$ ), which permits use, sharing, adaptation, distribution and reproduction in any medium or format, as long as you give appropriate credit to the original author(s) and the source, provide a link to the Creative Commons license and indicate if changes were made.

The images or other third party material in this chapter are included in the chapter's Creative Commons license, unless indicated otherwise in a credit line to the material. If material is not included in the chapter's Creative Commons license and your intended use is not permitted by statutory regulation or exceeds the permitted use, you will need to obtain permission directly from the copyright holder.

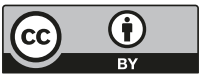

